\title{
Nikola Marinković
}

UDK: 821.163.42-31Desnica, V.:821.163.41.036.4

Izvorni znanstveni članak

Sažetak: U radu analiziramo mogućnosti čitanja Vladana Desnice iz ugla lirskog pripovedanja kao jednog od mogućih čitalačkih odgovora na savremeni izazov Desničine proze. Lirsko pripovedanje posmatramo kao način da se izbegnu zamke ideološki motivisanih interpretativnih pristupa i kao pristup poetički kompatibilan poetici i autopoetici Vladana Desnice. Kao primer lirskog pripovednog teksta analiziramo roman Proljeća Ivana Galeba u okviru koordinata lirskog pripovedanja zadatih dijahronijskim pregledom njegovog teorijskog promišljanja. Konačno, pružamo pregledni niz lirskih romana u srpskoj književnosti kao mogući kontekstualni okvir za novo i produbljeno sagledavanje književnoistorijskog lika Vladana Desnice. U zaključku posmatramo lirsko pripovedanje ne samo kao dijahronijsku činjenicu srpske književnosti već i kao novu mogućnost za ispitivanje sinhronijskih poetičkih i književnoistorijskih spona između srpske i hrvatske književnosti u segmentiranoj epohi književnog modernizma u vremenskom opsegu od rane moderne prve decenije dvadesetog veka do visokog modernizma šezdesetih i sedamdesetih godina prethodnog stoleća.

Ključne reči: Vladan Desnica, lirsko pripovedanje, lirski roman, autentičnost, subjektivizam, modernizam

I.

同 kcentuacija lirskog pripovedanja unutar drugih pripovednih modusa Vladana Desnice implicitno predstavlja jedan mogući odgovor na pitanje kakvu vrstu čitanja ova autorska figura može prizvati danas. Kako je naše čitanje gotovo podjednako opterećeno književnom tradicijom sa jedne i duhovnom situacijom trenutka sa druge strane, opravdana bojazan interpretatora tiče se raskoraka između ovih uzusa čitanja i interpretacije. $S$ jedne strane, prenaglašenim pozivanjem na tradiciju interpretator može svoj čin učiniti izlišnim, dok sa druge strane dolazi u blizinu jednog od češćih, ne uvek i nameravanih, ogrešenja kritike orijentisane na kontekst sadašnjosti: interferencije ideološke moći i hermeneutičkog čina. Otuda se kao primarni izazov nameće potraga za mogućnošću kontekstualizacije 
njegovog dela koja ostaje unutar ravnoteže između književnoistorijske tradicije i duhovne situacije vremena kao osnov širih interpretativnih zahvata.

Za tu kontekstualizaciju potreban nam je dvostruki fokus, kako na određene tematske, tako i na formalne komponente, koje ukupno daju određenu poetičku odliku. Istovremeno, pitanje konteksta dela određenog pisca unutar (nestabilnog) poretka jedne književne zajednice podrazumeva i pitanje odabira njegovog kanonskog dela kao konkretnog predmeta analize i polazne tačke ovakvog čitanja, što je u slučaju srpske (i hrvatske) književnosti roman Proljeća Ivana Galeba, pa ćemo osetljivom pitanju (re)kontekstualizacije Vladana Desnice prići upravo od ovog teksta.

Pre samog postupka (re)kontekstualizacije moramo ukazati na jedan od mogućih vidova interferencije moći i hermeneutičkog čina u jednom od mogućih savremenih teorijskih stanovišta pri tumačenju proze Vladana Desnice, koje bi moglo biti blisko onim poststrukturalističkim hermeneutikama koje insistiraju na jasno oblikovanom ideološkom okviru čitanja. Dijahronijski gledano, među prvim primerima ideologizovanog čitanja proze Vladana Desnice su tekstovi Jože Horvata „Margine“ iz 1952. odnosno Marina Franičevića „O slobodi stvaranja i tendenciji“ iz 1953. godine, koji su otvorili (neostvarenu) polemiku sa Desnicom koja se ticala osnovnih pretpostavki umetničkog stvaranja kao autonomnog i/ili društvenog čina. Društvenost spisateljskog čina je akcentovao sam Desnica u tekstu „Zapisi o umjetnosti“, dajući ironijsku definiciju „primijenjene književnosti“:

Analogija s likovnim umjetnostima porađa mi spasonosnu ideju: kao što su se tamo dodijelili i dobili svoje mjesto i položaj ogranci koji imaju praktične primjene, zašto da se to isto ne provede i na području književnosti? (...) Prestala bi trvenja i natezanja, sve bi praktičke, programatističke, utilitarne i slične tendencije našle svoje zadovoljenje. ${ }^{1}$

Horvat i Franičević su društvenost književnog čina formulisali sa eksplicitno ideoloških pozicija, time direktno spojivši hermeneutičku poziciju sa pozicijom moći. Horvat ističe: „Primijenjena književnost' kao i mnogi drugi dijelovi njegovih refleksija, još su jedan dokaz primjene reakcionarnih shvaćanja Vladana Desnice u oblasti teorije umjetnosti i društvene prakse. ${ }^{\text {" }}$ Sastavna sintagma s kraja citata pokazuje i hermeneutički spoj koji omogućava ovakvo čitanje: svako razumevanje umetnosti neminovno je i društveni čin ukoliko se zarad organizacije društtva sve oblasti ljudske duhovnosti podređuju toj svrsi.

Utilitarno razumevanje književnosti, poniklo u marksističkoj tezi o bazi i nadogradnji, kako pažljivije čitanje savremenijih teorijskih shvatanja pokazuje, nije sasvim nestalo sa scene, čak naprotiv. Mišel Fuko u pristupnom predavanju na Kolež de Fransu, održanom 2. 12. 1970. godine tvrdi:

1 Vladan Desnica, Progutane polemike, Beograd 2001., 20. 
Jedno i isto književno delo može pospešiti istovremeno izuzetno različite tipove diskursa: Odiseja se, u istom periodu, pojavljuje kao primarni tekst u prevodu Berara, u bezbrojnim objašnjenjima teksta, kao i u Džojsovom Uliksu. ${ }^{3}$

Problem sa ovakvim razumevanjem književnog teksta leži u Fukoovom razumevanju diskursa kao prostora moći koji ima svoju „policiju“ “ jer je i sam moć: „I pošto, kako nas istorija neprestano uči, diskurs nije prosto ono što borbe i sisteme dominacije prevodi u jezik, nego je on ono za šta se i čime se bori. Diskurs je moć koju treba zadobiti."

U nastavku svog pristupnog predavanja francuski filozof ističe da je i svaki obrazovni sistem „način da se održava ili menja prisvajanje diskursa, zajedno sa znanjima i moćima koje oni nose. ${ }^{\text {“6 }}$ No, kako je teorija književnosti takođe deo obrazovnog sistema to Fuko nešto zaobilaznijim putem takođe stiže na pozicije bliske Horvatovim, kada u (neimenovanu ali implicitnu) naporednost stavlja teoriju književnosti (i svaku drugu teoriju) i društvene prakse. Za Luja Altisera, Fukoovog uticajnog savremenika, književnost je deo državnih ideoloških aparata („kulturni DIA“) koji sveukupno služe posredovanju moći: „Koliko nam je poznato, nijedna klasa ne može posedovati državnu moć tokom dužeg perioda vremena, a da ne ostvaruje hegemoniju nad državnim ideološkim aparatima i kroz njih." "8

Ukoliko se iz ove perspektive vratimo na polemiku Desnice i Horvata (i Franičevića) videćemo da je u korenu tog sukoba temeljno različito razumevanje ljudske duhovnosti jer Desnica činom odvajanja „primijenjene“ od „one druge“ književnosti implicitno iznosi stav da postoji umetnost izvan ideologije što se, mutatis mutandis, razmimoilazi kako sa Horvatovim, tako i sa Fukoovim, a napose i stavovima Luja Altisera, koji dodaje i da „Za ono što se zaista odigrava u ideologiji nam se čini da se odigrava izvan nje." Prihvatanjem citiranog stanovišta morali bismo automatski odbaciti dobar deo Desničinih autopoetičkih i metapoetičkih stavova. Time se približavamo opasnoj poziciji da interpretirajući jednog pisca njemu samome oduzmemo glas, ${ }^{10} \mathrm{u}$ ime stanovišta koje implicitno i eksplicitno polazi od pretpostavke da je svaki teorijski govor deo određenog poretka moći što je slučaj sa mnogim poststrukturalističkim hermeneutikama.

Zato je neophodno vratiti se nedefinisanoj a značajnoj odrednici „ona druga“ književnost, koju Desnica kontrapunktira „primijenjenoj“, kao sve ono što „primijenjena“ književnost nije. U drugim fragmentima teksta „Zapisi o umjetnosti“, kao i u neobjavljenim odgovorima na Horvatove i Franičevićeve napade mogu se pronaći određene osobine i imenovanja „one druge“ književnosti. Tako u produžetku teksta „Zapisi o umjetnosti“ Desnica

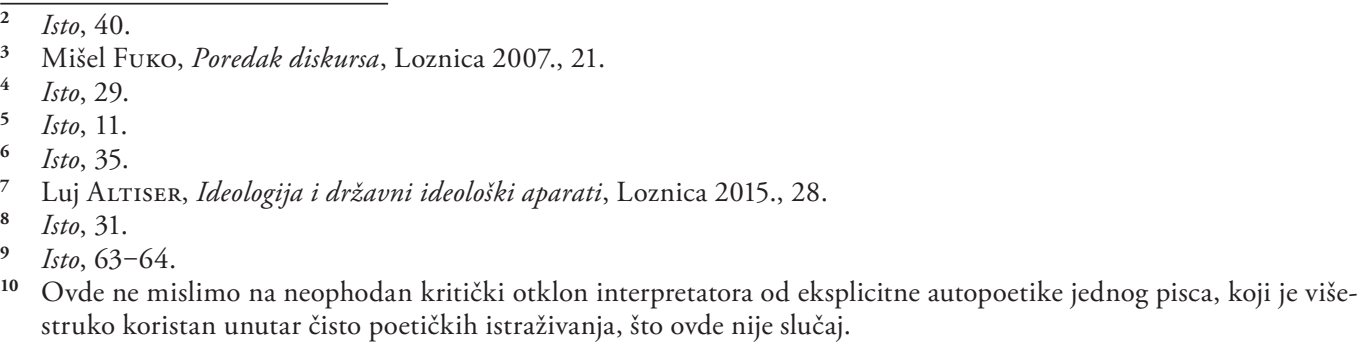


piše: „U književnom djelu svaka rečenica mora biti umjetnička. Čak i rečenice koje nam pružaju informacije i tehnička saznanja potrebna da bi se razumela fabula ili tok događaja moraju nositi u sebi neku estetsku vrednotu“. ${ }^{11} \mathrm{U}$ neobjavljenom tekstu „Nesporazumak oko 'primijenjene književnosti'“, napisanom 1952. godine, Desnica iznosi prividno tautološko stanovište da „umjetničko djelo, koje nije umjetničko djelo - nije naprosto ništa“"12 koje je zapravo zaključak prethodnog zapažanja da je umetnička strana nekog književnog dela njegova suština. Otuda se ovi stavovi mogu iščitati kao modernističko autonomističko razumevanje književnosti, unutar kojeg prethodni citat o estetskoj vrednosti svake rečenice proznoga teksta ima posebnu vrednost jer Desničinu autopoetiku približava poetici jedne posve modernističke forme: lirskog romana.

\section{3 .}

Lirsko, kao estetska kategorija i književnoteorijski termin, nije naročito starog datuma. Tek u osamnaestom veku lirika je ušla u trijadu književnih rodova. Isprva, u spisima opata Batea, kao njen specifikum postulirana je, prvo praksom, a potom teorijom, emotivnost, ${ }^{13}$ ali su temeljnije razumevanje pojma ponudili tek nemački romantičari, od kojih je za problematiku lirskog romana značajno osvrnuti se na ulogu poezije u teoriji Fridriha Šlegela.

U kritici Geteovog romana Godine učenja Vilhelma Majstera filozof romantizma piše: „Ova čudesna proza je proza, ali je zapravo poezija." 14 Time se roman koji stoji u osnovi čitavog jednog žanra (Bildungsroman, odnosno roman obrazovanja) postulira i kao reprezentant lirizacije epskog pripovedanja i povod takve konceptualizacije lirskog, što je značajno za razumevanje odnosa opšteg i pojedinačnog unutar lirskog kao (estetske) kategorije. Granične situacije života Vilhelma Majstera postaju okosnica prvog prepoznatog dela na granici proze i poezije ${ }^{15}$, čime tradicija na kojoj se teorijsko razumevanje lirskog romana zasniva od samog početka implicitno uključuje individualizaciju junaka njegovim graničnim situacijama izvan matrica epike.

Dalji koraci u definisanju lirskog vode putem naglašavanja subjektivnosti, pa tako Šeling za liriku kaže da „ona u poređenju sa svakim drugim vidom umetnosti neposrednije proizlazi iz subjekta" ${ }^{\text {"16 }}$. Novalis, još jedan savremenik nemačkog romantizma, takođe je nekoliko fragmenata o poeziji oblikovao oko semantičke ose opšte-posebno. ${ }^{17}$

11 V. Desnica, Progutane polemike, 32.

12 Isto, 66.

13 Miroslav Šutić, Lirsko i lirika, Beograd 1987., 35-39.

14 Friedrich Schlegel, Kritike i fragmenti, Zagreb 2006., 105.

15 Ovde treba napomenuti da Šlegelovo razumevanje poezije kao najčistijeg vida umetničkog stvaranja, odnosno poiesis-a ne odgovara današnjem pojmu poezije, ali je značajno što nemački filozof prepoznaje njen udeo u romanu koji je lišen kolektivnog zamaha karakterističnog za epiku u užem smislu već se fokusira na individuu unutar rađajućeg građanskog društva.

16 M. Šutić, Lirsko i lirika, 40.

$17 \mathrm{U}$ jednom od fragmenata nastalih 1797. - 1798. Novalis piše: „Poezija uzdiže sve pojedinačno posredstvom svojstvene povezanosti s preostalom sveukupnošću (...) Individuum živi u svemu i sve u individui. Posredstvom poezije nastaje najviša simpatija i koaktivnost, najiskrenije zajedništvo konačnog i beskonačnog." (Novalis, Filozofski fragmenti, Zagreb 2007., 80-81) 
Značajan pomak nastao je Ničeovim definisanjem liričara koji je „kao dioniski umetnik, potpuno poistovećen s Pra-Jednim, njegovim bolom i njegovom protivrečnošću“. ${ }^{18}$ Dionizijskom je „potrebno apolonsko da bi se lirski stvaralački postupak ostvario do kraja, da bi subjektivno preraslo u objektivno “. ${ }^{19}$ Objektivacija se stoga, jer u Pra-Jednom, dešava unutar suštinski mitskih imaginativnih prostora čime lirski pesnik postaje istinska figura totaliteta, nasuprot onog stvaraoca koji ostaje u neprekoračenoj subjektivnosti. Ovo Ničeovo rešenje problema objektivacije značajno je jer dozvoljava prelazak „lirske suštine u druge subjekte (...) on podrazumeva pojavu lirski zasnovanih likova u drugim književnim rodovima“. ${ }^{20} \mathrm{Na}$ putu prelaska lirskih kvaliteta u druge vrste književnosti i Kročeovo „vezivanje epiteta 'lirska' za intuiciju značajno je jer se ovde pojam lirskog, uz šire teorijsko obrazloženje, koliko znamo, po prvi put odlučnije odvaja od lirike kao žanrovskog pojma. Naravno, značenje pojma lirsko ostaje isto, izvorno." ${ }^{21}$

Jedan od retkih autora književnoteorijskih tekstova o lirskom romanu kao zasebnom žanru, Ralf Fridman, pokušao je da subjektivnost kao kategoriju lirskog poveže sa tipovima pripovednog govora: „Naglašavanje da je protagonist pesnikova maska neizbežno je u jednom žanru koji zavisi od analogije između lirskog 'ja' poezije u stihu i junaka romana. Kako je formalno prikazivanje jednog ja 'samorefleksivan' metod, najlirskiji romani zaista kao da traže jedno jedino gledanje na svet. “22 Precizniju formulaciju ove Fridmanove analogije možemo pronaći u jednoj od recentnijih definicija lirskog romana koja sažima ovu dihotomiju formalne neodređenosti i fenomenološkog jedinstva u tezu da je lirski roman lirski po sadržini a poetski po formi, u kojoj bi:

odrednica „lirski“ u terminu „lirski roman“ prizivala (...) koncepciju podele književnosti na tri roda: epski, irski, dramski; „lirsko“ bi tu označavalo aspekt ljudske egzistencije (...) „poetsko“ bi pak podrazumevalo (...) specifičnu vrstu vezanoga govora različitu od proznog ili dijaloškog iskaza, naglašavalo [bi] dakle, formalnu stranu književnog dela. ${ }^{23}$

Stoga i Jovićeva definicija lirskog romana (za koju sam autor u fusnoti ističe da prati Fridmanov trag, v. fusnotu 30 na 16. strani) ističe slikovnost $i$,subjektivnost ličnosti“ na „račun kauzalnog i temporalnog toka kazivanja“ ${ }^{24}$ čime se u razumevanje formalne strane lirskog romana i, posledično, lirskog pripovedanja, unose elementi vezani ne toliko za naratološka ispitivanja koliko oni nasleđeni iz interpretacije poezije, što podrazumeva da je prilikom intepretiranja lirskog romana podjednako važno, ako ne i pretežnije, analiziranje elemenata tropičnosti stila koliko i samih pripovedačkih strategija.

Teorijske implikacije subjektivnosti usložnjavaju se u vremenskom horizontu razvoja visokog modernizma u književnosti (prva polovina 20. veka) kada se subjektivnost, kao određujući pojam lirskog približava problematici pojma autentičnog u filozofiji. Autentično

\footnotetext{
Fridrih NičE, Rođenje tragedije, Beograd 1960., 33.

M. Šutić, Lirsko i lirika, 68.

Isto, 81-82.

Isto, 87.

22 Ralf Fridman, „Priroda i oblici lirskog romana“, Savremenik, 12/1968., 499.

23 Bojan Jović, Lirski roman srpskog ekspresionizma, Beograd 1994., 10.

24 Isto, 16.
} 
se neretko fundira unutar pozicije granične situacije, u kojoj se subjekat nalazi u „razrešenoj, faktičkoj, sebi samoj izvesnoj i strepećoj slobodi ka smrti““25. Ova sloboda osvaja se tek kao pozicija razrešenosti od onih situacija koje subjekta štite od apsolutne izloženosti čistoj egzistenciji, koja se kao takva otkriva tek u susretu sa smrću.

U poetici lirskog narativa ovi raznorodni elementi kristališu se u senzitivnu i nestabilnu poziciju pripovedajućeg subjekta/subjekta pripovedanja, odnosno u lični identitet kao okosnicu ovog tipa romana/pripovedanja. Ovo pripovedanje gotovo uvek je pripovedanje o smrti ili njenom obredno-socijalnom korelatu - graničnim situacijama egzistencijalnih prelaza pa predstavlja graničnu modernističku situaciju, odnosno, autora pred (permanentnom) smrću, namesto smrti autora koja kao teorijski koncept dolazi tek docnije. Subjekat, bez obzira na svoju konceptualnu krhkost u odsustvu čvrstog identiteta, ipak teži reintegraciji sopstva, te svoju jačinu pokazuje u tom neodustajanju od sebe uprkos permanentnim uvidima u kontradiktornosti i nekoherentnosti svoje pretpostavljene celovitosti.

U razuđenom tekstu Proljeća Ivana Galeba postoji mnoštvo momenata unutar kojih se pripovedački artikulišu navedene osobine lirskog pripovedanja. Problematika subjektivnosti unutar ovoga teksta determinisana je odnosom prema smrti kao temeljem egzistencije pripovedača:

Negde duboko zapretana u djetinjem biću leži jedna ćelija u kojoj tinja besmrtnost. A odmah do nje, u neposrednom susjedstvu, druga ćelija u kojoj drijema smrt. One žive u dobrim susjedskim odnosima. (...) Njihov naizmjenični dvopjev jest predivo našeg života. ${ }^{26}$

Odnos pripovedačke subjektivnosti prema smrti otvara mogućnost da se lirsko u Desničinom romanu fundira na konceptu autentičnosti kao svojem najdubljem tekstualnom sloju, na šta ukazuju i drugi delovi teksta. Njihovo prostiranje unutar teksta je brojno i složeno, pa ovde skrećemo pažnju na simbolički povlašćen iskaz Ivana Galeba o inicijaciji u svet umetnosti kao rezultanti susreta sa reifikovanom smrću na potkrovlju porodične kuće: „Lutao sam po tavanu i otkrivao u njemu razne zapasaje smrti. U tom se potkrovlju,

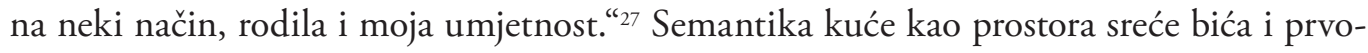
bitnog utočišta na taj način je destruirana uplivom fenomena koji to isto biće podvrgava rasapu, što bi, u slučaju razumevanja lirskog kao emotivnog kvaliteta ovog teksta, moralo rezultirati nereflektovanom nostalgijom kao tonom odnosa pripovedajućeg Ja prema samoj porodičnoj kući. Ipak, istovremeno uspostavljanje distance prema ovom prostoru u korist samostalnosti tog istog lirskog Ja pokazuje da je prevladavanje ove nostalgije (o čemu će kasnije biti reči) korak ka zadobijanju uvek izmičuće autentičnosti.

\footnotetext{
25 Martin Hajdeger, Bitak i vreme, 2007., 313.

26 V. Desnica, Proljeća Ivana Galeba, Podgorica 2003., 46-47.

27 Isto, 48.
} 
Blisko pozicijama autentičnosti je Galebovo razumevanje ljudskog bivstvovanja ${ }^{28}$ : „Jeza ništavila pokretač je svega u našem bivstvovanju, klica i nemir svakog kretanja i svakog traženja. Jer svako je čovječje traženje traženje jednog izlaza iz bezizlaza, svaki je njegov napor napor da provali iz obruča bezizlaznosti. “29 Međutim, ako je to kretanje kao kretanje od smrti prema Hajdegeru kretanje u neautentičnost, Galebovo ekspliciranje „jastva“ više naginje ka pojmu autentičnosti jer stremi ka (gotovo fenomenološkoj) redukciji svega spoljašnjeg, pa i vremena kao okvira bivstvovanja:

Kad reknemo ja mi time ciljamo na onaj isti subjekt, na onaj isti intimni osjećaj „jastva“ na koji smo ciljali i onda kad smo kao šesnaestogodišnjaci, ili šestogodišnjaci, izrekli tu zamjenicu ja. (...) Naše ja sastoji se iz golog fakta bivstvovanja i iz primarnog, slijepog osjećaja tog bivstvovanja. (...) Sve drugo je nebitno. ${ }^{30}$

$\mathrm{Na}$ tom drugom polu ovog semantičkog kretanja je prethodno pomenuta nostalgija. Narativno učinkovitija (jer motiviše nastavak pripovedanja, koliko god ga dosezanje autentičnosti privremeno usporava) nostalgija kao put (neretko i hronotopski oblikovan kao ponovni dolazak u prethodno napuštene topose) reintegracije ne vodi ka ucelovljavanju fenomenološkog, već istorijskog, vremenskog, dakle neautentičnog sopstva: „I nije to težnja za nečim što stoji napram našem biću, različito od njega: to je uvijek ona ista, stara žudnja za integracijom našeg ja, onaj pohod zbog iskupljenja jednog dijela sebe. “" ${ }^{31}$ Unutar ova dva pola, nostalgičnog i ,golog“ Ja, kao vremenskog i autentičnog Ja, širi se dijapazon motivacije različitih modusa pripovedanja, oba unutar kategorija lirskog. Sa jedne strane, emotivni naboj nostalgije daje ton deskripciji i otvara epizode kao nizove emotivnih sećanja, dok težnja ka uvek novom prisvajanju autentičnog Jastva doprinosi kidanju veza između protagoniste i njegove okoline i motiviše okonačnje i kratkoću istih tih epizoda kao bočnih narativa (što se može videti na primeru izrazite kratkoće narativa o ženi i ćerki).

Sadejstvo ova dva pola sustiče se u dva registra. U prvom, apstraktnost fenomena autentičnosti motiviše esejističnost pasaža u kojima pripovedačko lirsko Ja doseže bitne (za pojam autentičnosti) momente samorefleksije, ali kao osnov lirskog kvaliteta ovog teksta, metaforički se ova dva pola sustiču i unutar lajtmotiva sunca, koji istovremeno nosi semantiku izgubljenog vremena i prostora detinjstva, ali i diskurzivno nesaopštivog cilja egzistencije, koji svojom svedenošću odgovara (tek analogno) „golom“ Ja autentičnosti. Otuda i pojavljivanje ovog motiva na dva strukturno povlašćena mesta: početku i kraju teksta.

$\mathrm{Na}$ početku, sunce se javlja kao deo formativne deskripcije prostora kuće kao prostora u kojem se sustiču senovito i osunčano, unutar koje slike središte čini opis staklenih jabuka na vratima:

Na svim su vratima mjesto kvaka bile kugle od brušenog stakla. I te kugle kao da su bile ljepše na vratima sunčane strane: njihova zasićena plava boja čisto je živjela, kao da u njima gori po žižak. Iz dubine njihovog staklenog mesa izvijao se topli jantarnožuti svjetlac $\mathrm{i}$, $\mathrm{u}$

\footnotetext{
Već sama upotreba ovog termina otkriva filozofski obrazovanog pripovedača.

V. Desnica, Proljeća Ivana Galeba, 73.

30 Isto, 263.

31 Isto, 111.
} 
časovima jačeg razgaranja, probijao se na površinu. Na sjenovitoj strani, kugle su bile ugašene. Njihovo je plavetnilo bilo zamućeno, a u sredini kao da se nazirala rana, poput crva u srcu jabuke. ${ }^{32}$

Citirani pasaž pokazuje puteve kojima se apstraktna polarizacija (svetlo - tamno) upisuje preko metafore u mrtav predmet: nominalizacija predmeta (jabuka) vodi ka njegovoj vitalizaciji pa se na dva pola, svetlom i tamnom, nalaze dve vrste metafora, života (meso, svjetlac, razgaranje) i smrti (crv). Esejistički zamah autorefleksivnosti nedugo zatim u tekstu izvodi konceptualni zaključak iz ove čisto slikovne dihotomije, koja samog pripovedajućeg subjekta definiše kao imanentno lirskog, onog koji misli tropima a ne kategorijama:

Odatle i moja nesposobnost da dobro, lijepo, radost, harmoniju shvatim čisto pojmovno, bez primjese predstavnoga, već uvijek i jedino kao predstavu svjetlosti; i obratno, sve tužno i ružno, sve mrtvo i ledno, kao zakriljeno sjenom. Po tome, i naše misli mogu da budu osunčane ili sjenovite. Držim štoviše da se nikad ni ne rađa misao a da nije okupana u suncu ili zastrta sjenom. ${ }^{33}$

Motiv sunca time služi kao katalizator semantičkog kretanja koje ide od pripovedajućeg Ja ka svetu i vraća se njemu, pri tom oscilirajući između tropične i apstraktne refleksije, neposredno motivišući poetski i esejistički registar pripovedanja. Slojevitost i dubina ovog motiva omogućavaju mu da bude prenosnik različitih modusa lirskog kao autentičnog, što se vrhuni u jednom od strukturno najpovlašćenijih mesta u tekstu - u njegovoj poslednjoj rečenici: „Osjećam samo da nema stvarnijeg dobra od toga: mir sa radošću, s bolom - i preplavljenost suncem. “34 Konstrukcija poslednje rečenice i na sintaksičkom nivou ospoljava dva pola lirskog kao autentičnog: unutar svog drugog dela je pažljivo grafički markirana sintagma koju čine kategorijalni (mir sa radošću, mir sa bolom) i tropični deo (preplavljenost suncem). Istovremeno, narativna klackalica između nostalgije i autentičnosti rezolutno se okončava u korist druge što u konačnici fundira i modernost samog romana odabirom savremenijeg naspram prvobitnog elementa lirskog.

\section{5}

Ivan Galeb nije, međutim, jedini protagonista pripovednih tekstova srpske književnosti čija egzistencija se pripovedno oblikuje unutar analiziranih koordinata. Proljeća Ivana $G a-$ leba kao lirski roman nasleduju čitavom nizu srodnih ostvarenja. Početak i razvoj ovog niza vezan je za autorske figure čija duhovna fizionomija je formirana u dva granična područja srpske kulture: mediteranskom i srednjoevropskom.

U tom pretpostavljenom nizu, kao prvi lirski prethodnik Ivana Galeba svakako je Gavro Đaković, protagonista romana Bespuće Veljka Milićevića (1906./1912.). Izopštenost Đakovića iz okvira ustaljene egzistencije nije, kao u Galebovom slučaju, samoosvešćena, mož-

\footnotetext{
32 Isto, 7-8.

33 Isto, 8.

34 Isto, 339.
} 
da i stoga što se u njegovoj osujećenosti ne samo da dovrši svoje razvojne procese unutar obrisa građanskog društva (školovanje) i emotivno ostvari (odnos prema dvema ženskim figurama romana, Jekom i Irenom), već i da domisli ovo kretanje, ukazuje nejasna svest „o slomu epohe, koju je kroz dekonstrukciju bildungsromana Milićević naslutio mnogo pre nego što je Tomas Man, proširivši ovu dekonstrukciju na ravan dominantnog postupka, napisao Čarobni breg." ${ }^{35}$

Unutar objektivacija u mitskim slikama, Galebova fascinacija suncem takođe je deo šireg niza koji opet počinje Bespućem, od opisa vegetativnog ciklusa u Bespuću, preko fascinacije ekspresionistički toniranom prirodom u Dnevniku o Čarnojeviću, do gotovo potpune supremacije sunca kao najprodubljenijeg simbola u proznom lirskom ciklusu (nedovršenog romana $N a$ sunčanoj strani) Ive Andrića ${ }^{36}$ - Zanosi i stradanja Tome Galusa, Jelena, žena koja nema, Na sunčanoj strani, gde se sunce konfiguriše kao svakodnevni zalog egzistencije u ćeliji. U pripoveci Postružnikovo carstvo, poput Galebove epistemološke distinkcije, svet se takođe deli na sunčanu i tamnu stranu, Galusa i Postružnika:

Da, u stvari postoji samo sunce, a sve ovo što živi, diše, gamiže, leti, sja ili cvate, samo je odblesak toga sunca, samo jedan od vidova njegovog postojanja. sva bića i sve stvari postoje samo utoliko ukoliko u svojim ćelijicama nose rezerve sunčevog daha. Sunce je oblik i ravnoteža; ono je svest i misao, glas, pokret, ime. ${ }^{37}$

Bitno je dodati i da Andrićev nedovršeni roman kao pripovedni ciklus nastaje u rasponu od 1924., kada je objavljen prvi fragment iz duže pripovetke Jelena, žena koje nema, da bi se rad na njemu intenzivirao tridesetih godina, do 1960., kada je poslednji deo ove povesti objavljen, čime se Andrićev rad u znatnoj meri poklapa se sa Desničinim procesom rada na Proljećima Ivana Galeba. Uočeni i dijahronijski blizak poetički susret dve različite autorske figure pokazuje ukorenjenost lirskog pripovedanja unutar segmentiranog modernizma $\mathrm{u}$ srpskoj književnosti.

Lirska reintegracija sopstva unutar koordinata koje obrazuju ekstremno granične situacije egzistencije prisutna je i u prozama Danila Kiša, ponajviše u romanu Bašta, pepeo (1965.) i zbirci pripovedaka Rani jadi (1970.). Rituali jutra i detinjstva, kojima se otvara narativ $B a-$ šte, pepela pokazuju intenzitet osećajnosti i prijemčivosti za čulno opažanje Andreasa Sama koji ga konceptualno približavaju Ivanu Galebu, iako unutar kulturno-istorijski drugačijeg pripovednog sveta. Neprekidnost jastva Kišovog pripovedača naglašena je erudicijom stilizovanom u ironijskom ključu, čime se ostvaruje efekat naporednosti nostalgije i distance, koja je karakterstična i za Proljeća Ivana Galeba. Izazov autentičnosti u Kišovom romanu artikulisan je unutar dramatike odnosa junaka-pripovedača sa ocem na obrnut način u odnosu na Proljeća Ivana Galeba: dok u Galebovom slučaju nema potrebe za antagonističkim

35 Nikola Marinković, „Rekontekstualizacija romana Bespuće Veljka Milićevića. Čitanje iz ugla istorije žanra, arhetipskih modela i razvoja poetičkih obrazaca“, Savremena proučavanja jezika i književnosti. Zbornik radova sa VII naučnog skupa mladih filologa Srbije, Knj. 2 (ur. Maja Anđelković), Kragujevac 2016., 104.

36 U vezi sa Andrićem neophodno je ukazati i na Ex Ponto, lirski tekst na granici proze i poezije koji svojom zaokruženom, premda fragmentarnom narativnošću dozvoljava da se, uz izvesne ograde, o njemu može govoriti i kao o lirskom romanu.

37 Ivo Andrić, Na sunčanoj strani, Novi Sad 1994., 58. 
odnosom spram figure oca, jer je njene obrise nasledila figura dede (od koje, kao sinegdohe porodičnog okružja Ivan Galeb pokušava da se distancira), u slučaju Andreasa Sama prvo je rekonstruisana figura oca, Eduarda Sama, da bi ta distanca kao korak ka samostalnom jastvu bila uopšte moguća. Otuda se ova dramatika i proširuje na Rane jade, čija se mitopoetska srodnost sa Desničinim delom pojačava i motivom sunca unutar značajne pripovetke Zamak osvetljen suncem, ali proizvodi i Peščanik, kao istovremeno dokidanje i dovrhunjenje lirskog unutar Kišove proze, posle koje se oslobođeno pripovedačko Ja okreće drugim modusima pa i paradigmama.

Potpuna izopštenost odlikuje i junake pripovednih proza Branimira Šćepanovića, u kojima je važnost graničnih situacija do te mere naglašena da često izostaje njihova motivacija. Ključna sastavnica između ovog pripovednog iskustva i iskustva Proljeća Ivana Galeba jeste iskustvo blizine smrti, ali je istovremeno i katalizator njihove razlike. Dok je u Proljećima smrt reflektovana do samog maksimuma koji obležava potpuno iščeznuće svake diskurzivnosti u fragmentarnim pasažima koji prate operacije i krize Ivana Galeba pred kraj njegovog boravka u bolnici, to se u prozama Branimira Šćepanovića upravo ti krizni momenti samo akcentuju ali ne i reflektuju stoga što Šćepanovićeva lirska proza ispituje mogućnosti građenja narativa oko granične situacije kao pokretača pripovedanja. Ono što je jedan pol iskustva u Proljećima Ivana Galeba, u Ustima punim zemlje ili pripoveci Ono drugo vreme je dominantno iskustvo.

\section{6.}

Ukoliko, zbog značajne poetičke razlike, ostavimo po strani lirske romane Milovana Danojlića (iako bi obimnija studija na ovom tragu morala i njih da uzme u obzir), niz lirskih romana svakako ne bismo mogli da proglasimo niti konačnim niti zatvorenim. Romani Dragana Velikića mediteranskim ambijentom i postupcima reintegracije sopstva takođe nude mogućnost poetičke srodnosti sa navedenim lirskim romanima, ali je u njima i jasno prisutna trauma kolektiviteta kao drama raspada Jugoslavije, te junak recentnog Islednika (2015.) ne doseže uvek izrazitu individualnost junaka romana Via Pula (1988.). Ova razli$\mathrm{ka}$, međutim, nije samo poetičke prirode već je deo paradigme epohe.

Problemi subjektivnosti i autentičnosti, od značaja za lirsko pripovedanje, svojom artikulacijom u filozofiji i esejistici modernističkog razdoblja u dobroj meri su se ukazali kao teme na horizontu modernističkog pripovedanja, ali sa opadanjem modernizma prelaze $u$ drugi plan, prevashodno kroz paradigmatsko odustajanje od makar iluzije celine..$^{38}$ Time se pokazuje, u obrnutom smeru, i do koje mere su lirski roman i lirsko pripovedanje višestruko kulturnoistorijski uslovljena pojava, te unutar te uslovljenosti treba tražiti razloge i njihovog horizontalnog rasprostiranja, naspram ovde (fragmentarno) ponuđenog dijahronijskog niza.

\footnotetext{
38 Ograničenja ovog rada ne dopuštaju nam dublje bavljenje ovom temom, ali ipak treba ukazati da za razliku od makar prividne celine iskustva u Proljećima Ivana Galeba i drugim ovde pomenutim romanima, ključna narativna ostvarenja postmoderne u svoji značajnim poetičkim konačnicama upravo tu kategoriju napuštaju.
} 
Ova mogućnost horizontalnog razumevanja lirskog pripovedanja i mesta Vladana Desnice unutar njega, skupa sa kontaktnom prirodom njegove pojave u srpskoj književnosti, pruža dobre razloge da se lirsko pripovedanje sagledava i u srpsko-hrvatskom kontekstu. Istorijski modernizam, ovde posmatran u rasponu od Veljka Milićevića do proza Branimira Šćepanovića, istovremeno je i vreme institucionalizovanog trajanja jugoslovenske književne zajednice, što podrazumeva da se distribucija tema i postupaka između različitih književnosti, u ovom slučaju srpske i hrvatske, može zasnivati i na osnovama širim od poetičkih srodnosti dvaju nacionalnih modernizama.

Istovremeno, svojom orijentacijom na problem subjektiviteta, lirsko pripovedanje, prevashodno u lirskom romanu, može biti neprepoznat i izazovan interpretativni okvir za dijahronijske uvide u srpsku književnost dvadesetog veka. Neprepoznat, jer umesto interpretativno povlašćene akcentuacije istorijskog, lirsko pripovedanje nudi akcentovanje subjektivnog. Upravo zbog akcentovane subjektivnosti, ova tradicija se nameće kao dvostruko opravdani okvir kontekstualizacije Vladana Desnice: granično kulturološko poreklo, formalna srodnost, tematska istovetnost, mitološke slike - ukupno jedna lirsko-individualistička linija u srpskoj književnosti koja u bitnome upotpunjava Desničin književnoistorijski lik, ali koja je dvostruko osujećena u savremenom trenutku, kako zbog postmodernizmu bliskog dekonstruisanja subjektiviteta, kao i svega drugog, na dekomponovan tekst, tako zbog i dalje preovlađujućeg bavljenja istorijskim narativom i kanonom, koje nije sasvim lišeno ideološkog predumišljaja.

\section{$\cos$}

\section{The lyrical nOVEl and Vladan DesniCA's LyriCAL NARRATION IN THE CONTEXT OF SERbian Literature}

One of the ways to respond to the challenge of Vladan Desnica's fiction is to interpret it in light of lyrical narration. Focusing on lyrical narration helps avoid the pitfalls of ideologically coloured readings which give the illusion of being markedly contemporary within the choice of a theoretical paradigm, as well as an excessive reliance on the tradition of earlier interpretations. The approach is additionally justified by its compatibility with Desnica's poetics and autopoetics. The novel Proljeća Ivana Galeba (The Springs of Ivan Galeb) is provided as an example of lyric fiction. The analysis is set within a framework of a diachronic overview of the theoretical views of the lyrical as a phenomenon within different philosophical, aesthetical and theoretical approaches which, viewed together, sufficiently support the assumption that lyrical narration should be recognized as a specific narrative mode in Desnica's novel. Such an analysis reveals a semantic opposition between nostalgia and authenticity in which the lyrical narrator moves and which motivates the use of different narrative techniques, from essayistic elements to poetic narration laden with tropes. In a comparative historical overview, the analyzed elements of the novel The Springs of Ivan Galeb were analyzed within a supposed tradition of lyrical novels in Serbian literature, thus providing a possible contextual framework for a new, more thorough understanding of Vladan Desnica and his position in literary history. This tradition proves to be a diachronically and poetically limited literary and historical phenomenon within which it is possible to track the problem of shaping sensitive modern subjecti- 
vity in fiction. Poetically determined by literary modernism, the lyrical novel and lyrical narration provide a new, unacknowledged opportunity to examine synchronic poetic and literary-historical connections between Serbian and Croatian literature in the segmented period, spanning from the early modernism of the 1910s to the high modernism of the 1960s.

Key words: Vladan Desnica, lyric fiction, lyrical narration, the lyrical novel, authenticity, subjectivism, modernism

\section{cos}

\section{Literatura}

Luj Altiser, Ideologija i državni ideološki aparati, Loznica 2015.

Ivo Andrić, Na sunčanoj strani, Novi Sad 1994.

Vladan Desnica, Progutane polemike, Beograd 2001.

Vladan Desnica, Proljeća Ivana Galeba, Podgorica 2003.

Ralf Fridman, „Priroda i oblici lirskog romana“, Savremenik, 12/1968., 491-501.

Mišel Fuko, Poredak diskursa, Loznica 2007.

Martin Hajdeger, Bitak i vreme, 2007.

Bojan Jović, Lirski roman srpskog ekspresionizma, Beograd 1994.

Nikola Marinković, „Rekontekstualizacija romana Bespuće Veljka Milićevića. Čitanje iz ugla istorije žanra, arhetipskih modela i razvoja poetičkih obrazaca", Savremena proućavanja jezika i književnosti. Zbornik radova sa VII naučnog skupa mladih filologa Srbije, Knj. 2 (ur. Maja Anđelković), Kragujevac 2016., 97-106.

Fridrih NičE, Rodenje tragedije, Beograd 1960.

Novalis, Filozofski fragmenti, Zagreb 2007.

Friedrich Schlegel, Kritike i fragmenti, Zagreb 2006.

Miroslav Šutıć, Lirsko i lirika, Beograd 1987. 